\title{
MENUJU PEMERINTAHAN ELEKTRONIK YANG TRANSFORMATIF
}

Sejak kampanye 2019, pemerintahan Jokowi telah menggalakan visi Indonesia digital melayani. Visi tersebut telah dibidani dengan Peraturan Presiden No. 95 tahun 2018 tentang Sistem Pemerintahan Berbasis Elektronik yang mengatur Rencana Induk SPBE Nasional dan integrasi layanan elektronik. Sistem pemerintahan elektronik yakni transformasi pelayanan publik baik secara internal dan eksternal melalui teknis operasional tupoksi dan teknologi informasi dan komunikasi untuk meningkatkan pelayanan dan partisipasi dalam pemerintahan (Salleh \& Ahmad, 2006). Meski demikian, sejak virus korona ditetapkan sebagai pandemi pada pertengahan Maret 2020 lalu, beberapa pelayanan publik seperti sistem belajar mengajar dan pengajuan izin dilakukan dari jarak jauh atau menggunakan piranti digital. Meski demikian, banyak instansi pemerintah yang mengakui bahwa beberapa pengguna layanan tidak dapat mengakses piranti digital karena keterbatasan infrastruktur dan kemampuan menggunakanya (Walton \& Rahemtulla, 2020). Selain itu, penerapan pelayanan publik elektronik atau e-government di Indonesia juga mengalami sejumlah tantangan antara lain perbaikannya yang masih tergantung pada dukungan finansial dan budaya birokrasi yang kurang mendukung (Aritonang, 2017). Permasalahan keramahan pada pengguna juga telah diprediksi sebelumnya (Sukmasetya, Santoso, \& Sensuse, 2018).

Permasalahan lain yakni rasio jumlah PNS terhadap penduduk saat ini yakni setiap 100 penduduk dilayani oleh 1, 7 pegawai, ini cukup jauh dengan Singapura yang memiliki rasio 2,5\% dan Malaysia 3,7\% (Rakhmawanto, 2016). Dengan rasio tersebut, kompetensi digital belum diprioritaskan bagi ASN di Indonesia terutama kompetensi e-government dan digitalisasi pelayanan, padahal kompetensi tersebut sangat penting dalam penyelenggaraan pemerintahan yang efektif ("Government at a Glance Southeast Asia 2019," n.d.). Dengan penerapan e-government, batas ruang dalam pelayanan publik menjadi hilang sehingga pelayanan lebih cepat dan mudah diakses (Aritonang, 2017). E-government juga berasosiasi positif terhadap kinerja administrasi pemerintah daerah di Indonesia (Sutopo, Wulandari, Adiati, \& Saputra, 2017). Maka itu, memprioritaskan kompetensi digital dan transformasi $e$ government perlu menjadi langkah awal yang perlu segera dilakukan saat ini.

Saat ini posisi peringkat Indonesia dalam e-government Index berada di peringkat ke tujuh dari 10 negara ASEAN setelah Singapura, Malaysia, Thailand, Brunei Darussalam, Filipina, dan Vietnam (United Nations E-Government Survey 2020: Digital Government In The Decade Of Action For Sustainable Development, n.d.). Meski Indonesia telah naik 18 peringkat dibandingkan dengan tahun sebelumnya, isu infrastruktur, kurangnya kualitas sumber daya manusia dan kesiapan pengguna masih menjadi masalah yang muncul, maka, sebuah kajian merekomendasikan agar pemerintah membangun program komperhensif yang mengases teknologi, keasiapan warga, dan dimensi lingkungan dalam mendukung pemerintahan elektronik (Sabani, Deng, \& Thai, 2019). Jika kita melihat lebih detail berdasar data perbandingan tabel berikut, Indonesia masih tertinggal terutama dalam kualitas SDM dan penetrasi internet. 
Tabel 1.Perbandingan Aspek yang Mempengaruhi E-government dengan Enam Negara ASEAN Lainnya

\begin{tabular}{|c|c|c|c|c|c|c|c|}
\hline & Singapura & Brunei & Malaysia & Thailand & Filipina & Vietnam & Indonesia \\
\hline $\begin{array}{l}\text { PDB Nominal } \\
\text { Perkapita } \\
\text { dalam USD }\end{array}$ & 58,484 & 31,081 & 10,192 & 7,295 & 3,373 & 3,498 & 4,038 \\
\hline $\begin{array}{l}\text { Presentase SDM } \\
\text { yang } \\
\text { berpendidikan } \\
\text { dan berkeahlian } \\
\text { tinggi }\end{array}$ & $55 \%$ & $\begin{array}{l}\text { Tidak } \\
\text { ada } \\
\text { data }\end{array}$ & $25 \%$ & $14 \%$ & $24 \%$ & $10 \%$ & $9 \%$ \\
\hline $\begin{array}{l}\text { Penetrasi } \\
\text { Internet }\end{array}$ & $89 \%$ & $95 \%$ & $84 \%$ & $67 \%$ & $43 \%$ & $69 \%$ & $48 \%$ \\
\hline
\end{tabular}

Dari data di atas, kita dapat mengambil pembelajaran bahwa penetrasi internet dan kualitas SDM adalah prasyarat utama dalam transformasi e-government. Kita juga dapat menarik pembelajaran dari Thailand dan Malaysia di mana 20 tahun yang lalu kualitas SDM dan penetrasi internet bahkan di bawah Indonesia namun kini mereka lebih unggul dalam penerapan e-government.

Thailand telah memulai kerangka kerja kebijakan e-government sejak tahun 1990, kini Pemerintah Thailand mengimplementasikan versi transformasi digital 4.0 untuk meningkatkan daya saing bisnis, kesejahteraan warga, perlindungan lingkungan, dan kinerja sektor publik. Kunci penerapan e-government di Thailand terdapat pada integrasi $e$ government oleh pemerintah pusat. Koordinasi digital dimulai dari dua instansi kunci pengelola e-government di Thailand yakni Menteri Ekonomi Digital dan Badan Pelayanan Elektronik. Kedua instansi tersebut menyusun kebijakan dan mengatur sumber daya pusat terhadap beberapa level yang berbeda dan mengintegrasikan kebijakan pemerintahan digital antar level dan antar sektor dengan instrumen kontrol pusat (Sagarik, Chansukree, Cho, \& Berman, 2018).

Wewenang Badan Pemerintahan Elektronik di Thailand yakni Menyusun kebijakan pemerintahan elektronik yang konsisten melalui melalui beberapa level, dari level strategis hingga ke level rencana aksi kegiatan yang lebih kecil dalam mengelola koherensi di seluruh sektor. Peran terbesar dari badan tersebut yakni koordinasi dan integrasi vertikal dan horizontal antar-instansi dan peningkatan kompetensi dan standar instansi pelaksana pemerintahan elektronik. Dengan sentralisasi tersebut instansi pemerintah tetap proaktif dan meningkat kinerjanya (Sagarik et al., 2018).

Jika kunci implementasi pemerintahan elektronik di Thailand adalah sentralisasi, sentralisasi pun berkontribusi terhadap pelaksanaan e-government di Malaysia dengan penambahan faktor lain yakni perumusan tujuan, gaya manajerial organisasi dan sentralisasi, demikian sebuah survei menyimpulkan dari 201 instansi pusat di Malaysia yang menyelenggarakan pemerintahan elektronik (Lean, Zailani, Ramayah, \& Fernando, 2009). Perumusan tujuan meliputi koherensi antara tujuan organisasi dan ketepatan instrumen teknologi dalam mencapainya, gaya menajerial meliputi kemampuan seorang manajer dalam memotivasi, mempengaruhi pegawai dalam mengambil keputusan tepat dalam mencapai tujuan organisasi, sedangkan sentralisasi meliputi ketegasan koherensi implementasi kebijakan dalam pemerintahan elektronik (Lean et al., 2009). Malaysia juga menghadapi masalah keterbatasan infrastruktur dalam penyelenggaraan pemerintahan 
elektronik, namun kendala tersebut diatasi dengan faktor kontribusi kesuksesan $e$ government yakni kinerja tim dan manajemen pengetahuan yang sinergis dan terbuka. (Salleh \& Ahmad, 2006)

Dari Thailand dan Malaysia, Indonesia dapat belajar pentingnya kebijakan pemerintahan elektronik yang terintegrasi dan tersentralisasi, serta pentingnya memprioritaskan kompetensi digital baik aparatur dan warga secara umum. Sebab kompetensi digital diperlukan agar bentuk layanan elektronik lebih mudah diadaptasi dan diterima serta diketahui potensinya dan sentralisasi dan integrasi layanan juga diperlukan untuk menyederhanakan prosedur pendataan dan keamanan data siber. Dengan kedua hal tersebut terlaksana, didukung pemerataan infrastruktur, pemerintahan elektronik di Indonesia dapat memberikan manfaat yang strategis bagi kesejahteraan warga (Pratiwi).

\section{Referensi :}

Aritonang, D. M. (2017). The Impact of E-Government System on Public Service Quality in Indonesia. European Scientific Journal, 13, 35-99.

GDP Per Capita, Current Prices. (2020). IMF. Retrieved from imf.org/external/datamapper/PPPPC@WEO/THA

Government at a Glance Southeast Asia 2019. (n.d.). Paris: OECD Publishing. Retrieved from https://doi.org/10.1787/9789264305915-en

Human Capital Outlook: Association of Southeast Asian Nations (ASEAN). (2016). Retrieved from https://www.weforum.org/reports/human-capital-outlook-association-of-southeastasian-nations-asean

Individuals using the Internet (\% of population). (2019). Bank Dunia. Retrieved from https:// data.worldbank.org/indicator/IT.NET.USER.ZS

Lean, O. K., Zailani, S., Ramayah, T., \& Fernando, Y. (2009). Factors influencing intention to use e-government services among citizens in Malaysia. International Journal of Information Management, 29(6), 458-475.

Rakhmawanto, A. (2016). Rasionalisasi Kebutuhan dan Distribusi PNS Nasional (No. 002). Jakarta. Retrieved from https://www.bkn.go.id/wpcontent/uploads/2014/06/Policy-Brief-Distribusi-PNS20-10-2016.pdf

Sabani, A., Deng, H., \& Thai, V. (2019). Evaluating the Development of E-Government in Indonesia. In Proceedings of the 2nd International Conference on Software Engineering and Information Management (pp. 254-258).

Sagarik, D., Chansukree, P., Cho, W., \& Berman, E. (2018). E-government 4.0 in Thailand: The role of central agencies. Information Polity, 23(3), 343-353.

Salleh, K., \& Ahmad, S. N. S. (2006). KM strategy for E-Government: An exploratory study of Local Authorities in Malaysia. In Proceedings of the Knowledge Management International Conference $\mathcal{E}$ Exhibition 2006.

Sukmasetya, P., Santoso, H. B., \& Sensuse, D. I. (2018). Current E-Government Public Service on User Experience Perspective in Indonesia. In 2018 International Conference on Information Technology Systems and Innovation (ICITSI) (pp. 159-164).

Sutopo, B., Wulandari, T. R., Adiati, A. K., \& Saputra, D. A. (2017). E-government, audit opinion, and performance of local government administration in Indonesia. Australian Accounting, Business and Finance Journal, 11(4), 6-22.

United Nations E-Government Survey 2020: Digital Government In The Decade Of Action For Sustainable Development. (n.d.). Retrieved from https://publicadministration.un.org/ egovkb/Portals/egovkb/Documents/un/2020Survey/2020 UN E-Government Survey (Full Report).pdf 
Walton, K., \& Rahemtulla, H. (2020). At your service: Indonesia's government agencies look to digital innovations amid COVID-19. ADB Blog. Retrieved from https://blogs.adb.org/blog/your-service-indonesia-s-government-agencies-lookdigital-innovations-amid-covid-19 